\title{
Interpreting the Customary Rules on Interpretation
}

\author{
Panos Merkouris \\ University of Groningen \\ p.merkouris@rug.nl
}

\begin{abstract}
International courts have at times interpreted the customary rules on interpretation. This is interesting because what is being interpreted is: i) rules of interpretation, which sounds dangerously tautological, and ii) customary law, the interpretation of which has not been the object of critical analysis. The present paper, aims to fill this lacuna and prove that not only interpretation of customary rules of interpretation is not problematic (it is neither tautological nor impossible), but also that it is a process completely distinguishable from that of formation/identification of customary international law. Whereas the latter determines the existence of a customary rule and has to grapple with 'practice' and 'opinio juris', interpretation of customary rules concerns itself with the rules after they have come into existence. I will then demonstrate that customary rules of interpretation have consistently been interpreted in international jurisprudence and that the interpretative process bears certain similarities to treaty interpretation.
\end{abstract}

\section{Keywords}

interpretation - interpretation of treaties - interpretation of customary international law - customary international law - induction - deduction - assertion - Vienna Convention on the Law of Treaties

\section{$1 \quad$ Introduction}

Lord McNair, famously stated that the 'there is no part of the law of treaties which the text-writer approaches with more trepidation than the question of interpretation.' ${ }^{1}$ However, it seems that for a long time now, and especially

1 Arnold D. McNair, The Law of Treaties (1961), 364. 
post-VCLT (Vienna Convention on the Law of Treaties), international courts and tribunals have taken in their stride such interpretative operations without batting an eye. What is striking is that the rules that are being interpreted are the rules of interpretation themselves, and in fact not just the VCLT rules on interpretation, but also their customary law counterparts. ${ }^{2}$ This is surprising for two main reasons:

1) what is being interpreted is rules of interpretation, which runs the danger of sounding and being tautological in nature, and

2) what is being interpreted is customary law, which in and of itself is quite surprising as literature seems to focus entirely on interpretation of treaties. $^{3}$

The present paper aims to fill this lacuna and prove that not only interpretation of customary rules of interpretation is not problematic (it is neither tautological nor impossible), but also that it is a process that should be completely distinguished from that of formation/identification of customary international law. ${ }^{4}$ Whereas the latter determines the existence of a customary rule and therefore by necessity it has to grapple with 'practice' and 'opinio juris', interpretation of customary rules ${ }^{5}$ concerns itself with the rules after they have been formed/identified. Consequently, interpretation of customary rules is not bound by the straightjacket of 'practice' and 'opinio juris', and those customary rules can be allowed to breathe freely and evolve in the same way that treaty rules do. Having done that, I will then demonstrate that customary rules of interpretation have consistently been interpreted in international jurisprudence and the interpretative process is based mutatis mutandis on the same rules that are used for interpretation of treaty rules.

Based on the above considerations, this article will address the following issues in the Sections to follow. Section 2 will demonstrate the timeliness of the present inquiry in the context of a surge in interest and research with respect to both CIL as a source of international law and the process of interpretation

2 On the customary nature of the rules of interpretation, see indicatively: Arbitral Award of 31 July 1989 (Guinea-Bissauv. Senegal), Judgment, ICJ Reports 1991, para. 48; Maritime Delimitation and Territorial Questions between Qatar and Bahrain (Qatarv. Bahrain),Judgment, ICJ Reports 1995, para. 33 (hereinafter Qatar v. Bahrain case); Oil Platforms (Preliminary Objections) (Islamic Republic of Iran v. United States of America), Judgment, ICJ Reports 1996, para. 23.

3 For an extensive list of authorship on the matter see infra note 15 .

4 See also: Jean d'Aspremont, "The Idea of 'Rules' in the Sources of International Law", 84 BYIL (2014), pp. 103-130.

5 Any customary rule, including the customary rules of interpretation as will be shown in the Sections to follow. 
in general. In this milieu it is interesting to engage in a discussion as to whether CIL rules can be interpreted in a fashion similar to the rules contained in treaties. In Section 3, some basic concepts surrounding the discussion of interpretation of CIL rules will be analysed. Firstly, it will be shown that despite the rejection of the interpretability of CIL rules, legal theory and practice seem to indicate the exact opposite. ${ }^{6}$ Second, induction and deduction will be shown to be methodologically apposite to different stages in the 'life-cycle' of any CIL rule. ${ }^{7}$ Whereas induction is critical to the formation and identification of a 'proto-stage' of CIL, deduction is more apposite to the interpretation of a CIL rule. This means that once a CIL rule has come into existence, the further clarification of its content, in most instances, will not be amenable to the inductive process of resorting to State practice and opinio juris, but rather will be achieved through an interpretative process stricto sensu. ${ }^{8}$ Within this discussion, it will also be demonstrated that the expression 'interpretation of State practice' is a misnomer. It is not interpretation in the strict sense, but rather evaluation of the importance of State practice in the process of the formation a CIL rule. Consequently, it is substantively and substantially different from the process of interpretation of CIL rules, with which the present Article deals. Section 4 will examine the treaty and jurisprudential evidence that prove the interpretability of CIL. Finally, Section 5 will demonstrate that the interpretability of cIL rules is not only possible and has occurred, but it is so ubiquitous that it has manifested even in cases when the object of interpretation is not any random CIL rule, but the CIL rules of interpretation themselves. In order to prove that CIL rules can be interpreted it would have been sufficient to demonstrate even one CIL rule having been interpreted. However, if even the CIL rules of interpretation can be interpreted, this is proof that the process of interpretation is part and parcel of the existence and functioning of even the unwritten rules of CIL and without it the application of CIL rules would run into insurmountable logical paradoxes.

6 This point, central to the entirety of this Article, will be further elaborated in Sections 3, 4 and 5 .

7 Assertion being 'methodological-less' will feature only to the extent necessary to show that it should be considered as a proper method of determining either the formation or interpretation of a cIL rule.

8 Which is familiar to everyone in the context of treaty interpretation. 


\section{Resurgence of Interest in Interpretation and Customary International Law}

In international law interpretation is ubiquitous and is the process through which the interpreter attempts to determine the meaning of the rule that is being interpreted. Its importance is evident by the mere fact that every case brought before international courts and tribunals has dealt one way or another with questions of interpretation.

Customary international law (CIL), in turn, is one of the formal sources of international law and together with treaties are the most important ones, creating binding rules of international law. Some of the most crucial rules of international law started and continue to exist as CIL. ${ }^{9}$ Examples of CIL rules are: the prohibition of genocide and torture, the prohibition of slavery and piracy, the rules on State responsibility, the principle of non-refoulement and the no-harm rule, to name but a few. It is undeniable that all of these cIL rules have made and continue to make a vital contribution to international law and society. CIL's importance is further underlined by the fact that its rules also cover areas that have not been regulated by treaties, that general CIL is binding on all States, ${ }^{10}$ and that several systemic rules are customary in nature, such as the rules governing the resolution of normative conflict. ${ }^{11}$ The issue with CIL, however, is that it is an unwritten source of international law. Its existence is determined inductively through an examination of two elements, state practice and opinio juris. ${ }^{12}$

There has never before been a time when international law affected and regulated so many areas of human activity as it does today. The proliferation of international rules and of international courts and tribunals makes the need for clarification of how the sources of international law are being interpreted and applied ever so imperative. In such an expanding international legal landscape, where CIL remains one of the main sources of international law, it is inconceivable to be still stumbling in the dark as to how CIL rules are being interpreted. If such a situation is left unchecked, this will have deleterious effects for the international legal system both at a micro- (parties to a dispute)

$9 \quad$ Certain of these have also been codified in treaties.

10 Whereas a treaty is binding only on its parties.

11 Joost Pauwelyn, Conflict of Norms in Public International Law: How WTO Law Relates to Other Rules of International Law (2003).

12 North Sea Continental Shelf (Germany/Denmark and the Netherlands), Judgment, ICJ Reports 1969, para. 44. 
and a macro-level (all 'users'/'participants' of international law). ${ }^{13}$ They would lose faith in the legal certainty of the international legal system and as a result would have increasingly less incentive to make use of the dispute settlement procedures due to their unpredictability. In that manner the lack of foreseeability would undermine the effectiveness and stability of the international legal system as a whole. CIL's role in the functioning of the international legal system is too critical to be left to chance or even worse to 'judicial assertions'. This need becomes even more imperative, when considering that the rules of interpretation may themselves be the subject of change. ${ }^{14}$ Therefore they need to be an object of meticulous study.

Of course there has been no shortage throughout the ages of writings on both interpretation ${ }^{15}$ and CIL. ${ }^{16}$ However, at this particular juncture there

13 For the meaning of these terms see: Emmanuel Roucounas, "Facteurs privés et droit international public", $299 R d C$ (2003), pp. 9 et seq.; Emmanuel Roucounas, "The Users of International Law", in M.H. Arsanjani et al. (eds.), Looking to the Future: Essays on International Law in Honor of W. Michael Reisman (2011), pp. 217-234; Rosalyn Higgins, Problems and Process: International Law and How we Use it (1994), pp. 39-55; Rosalyn Higgins, Themes and Theories: Selected Essays, Speeches, and Writings in International Law (2009), pp. 74-90.

14 Donald Greig, Intertemporality and the Law of Treaties (2001), pp. 113-114; Hazel Fox, "Article 31(3)(a) and (b) of the Vienna Convention and the Kasikili/Sedudu Island Case", in M. Fitzmaurice, O. Elias and P. Merkouris (eds.), Treaty Interpretation and the Vienna Convention on the Law of Treaties: 30 Years on (2010), pp. 64-65; Ulf Linderfalk, "The Application of International Legal Norms Over Time: the Second Branch of Intertemporal Law", 58/2 NILR (2011), pp. 163-165; Malcolm Shaw, "Case Concerning Kasikili/Sedudu Island (Botswana/Namibia)", 49 ICLQ (2000), p. 968; Panos Merkouris, “(Inter)temporal Considerations in the Interpretative Process of the VCLT: Do Treaties Endure, Perdure or Exdure?", 45 NYIL (2014), pp. 147-150; Jan Erik Helgesen, "What are the Limits to the Evolutive Interpretation of the European Convention on Human Rights?", 31 HRLJ (2011), p. 275 .

15 Hugo Grotius, (Clement Barksdale transl. and annot.), De jure belli ac pacis (The Illustrious Hugo Grotius of the Law of Warre and Peace with Annotations. III Parts and Memorials of the Author's Life and Death) (1654), Book II, Chapter XVI; Emmerich de Vattel, The Law of Nations or Principles on the Law of Nature Applied to the Conduct and Affairs of Nations and Sovereigns (1793), Book II, Chapter XVII; Samuel Pufendorf ([s.n.] transl.), Of the Law of Nature and Nations (1703), Book V, Chapter XII; Gerald Fitzmaurice, "The Law and Procedure of the International Court of Justice 1951-54: Treaty Interpretation and Other Points", 33 BYIL (1957), p. 203; Hersch Lauterpacht, The Development of International Law by the International Court (1958); Richard Gardiner, Treaty Interpretation (2nd ed., 2015), p. 251; Robert Kolb, Interprétation et création du droit international: esquisses d'une herméneutique juridique moderne pour le droit international public (2006); Malgosia Fitzmaurice and Olufemi Elias, Contemporary Issues in the Law of Treaties (2005), 
seems to have been a spike in interest and research with respect to both these areas. On the one hand, international law seems to be going through a similar process as mathematics in the 19th century. It has become obvious that in order for international law to progress as a science, we need to identify the axioms on which the system is based, as well as the rules under which the 'building blocks' of the international legal system function. Although the study of the sources of international law has, similarly to interpretation, never been entirely out of fashion, in the late 2oth and early 21st century there has been a resurgence in the efforts to clarify CIL. The International Law Association, for

Chapter 3. There are also always new issues emerging. See for instance: Georg Nolte (ed.), Treaties and Subsequent Practice (2013); Panos Merkouris, Article 31(3)(c) VCLT and the Principle of Systemic Integration: Normative Shadows in Plato's Cave (2015); Vassilis Tzevelekos, "The Use of Article 31(3)(c) of the VCLT in the Case Law of the ECtHR: an Effective Anti-Fragmentation Tool or a Selective Loophole for the Reinforcement of Human Rights Teleology?", 31/3 Michigan Journal of International Law (2010), pp. 621-69o; Jean d'Aspremont, "The Multidimensional Process of Interpretation: Content-determination and Law-ascertainment Distinguished", in A. Bianchi, D. Peat and M. Windsor (eds.), Interpretation in International Law (2015), pp. 111-129.

16 Michael Akehurst, "Custom as a Source of International Law", 47 BYIL (1977), pp. 1-53; Peter Haggenmacher, "La doctrine des deux éléments du droit coutumier dans la pratique de la Cour internationale", 90 RGDIP (1986), pp. 5-125; Alain Pellet, "Article 38", in A. Zimmermann, Chr. Tomuschat and K. Oellers-Frahm (eds.), The Statute of the International Court of Justice: A Commentary (2nd ed., 2012), pp. 731-870; Hugh Thirlway, International Customary Law and Codification: An Examination of the Continuing Role of Custom in the Present Period of Codification of International Law (1972), pp. 46-6o; Photini Pazartzis, "Le rôle de la pratique dans le droit coutumier", in R. Huesa Vinaixa (ed.), L' influence des sources sur l' unité et la fragmentation du droit international (2006), pp. 81-102; Serge Sur, La coutume internationale (1990); Charles de Visscher, "La codification du droit international", 6/I RdC (1925), pp. 349-66; Jean d'Aspremont, Formalism and the Sources of International Law: A Theory of the Ascertainment of Legal Rules (2011); Michael P. Scharf, Customary International Law in Times of Fundamental Change: Recognizing Grotian Moments (2013); Jack L. Goldsmith and Eric A. Posner, Limits of International Law (2007), pp. 3-78; Jack L. Goldsmith and Eric A. Posner, "A Theory of Customary International Law", 66/4 University of Chicago Law Review (1999), pp. 1113-1177; Joel P. Trachtman, "The Growing Obsolescence of Customary International Law", in C.A. Bradley (ed.), Custom's Future: International Law in a Changing World (2016), pp. 172-204; Vassilis P. Tzevelekos, "Juris Dicere: Custom as a Matrix, Custom as a Norm, and the Role of Judges and (their) Ideology in Custom Making", in N.M. Rajkovic, T. Aalberts and Th. Gammeltoft-Hansen (eds.), Power of Legality: Practices of International Law and their Politics (2016 forthcoming - on file with the author); Jean d'Aspremont, "The Decay of Modern Customary International Law in Spite of Scholarly Heroism", available at: http://papers.ssrn.com/ sol3/papers.cfm?abstract_id=2756904 (last accessed on 20 January 2016). 
instance, had a 17-year (1984-200o) project on the formation of general customary international law. ${ }^{17}$ More recently, the International Law Commission (ILC), with Sir Michael Wood acting as Special Rapporteur, has taken up the challenge of illuminating this mercurial process by initiating a study on the identification of CIL, that started in 2013 and is expected to complete its work in $2017^{18}$

On the other hand, there is also a great focus at the international level for clarification of the rules of interpretation with the $\mathrm{ILC}^{19}$ and its respective Special Rapporteurs in the last few years having devoted several of its topics under consideration to interpretative issues. Indicatively, I mention the ILC's work on:

- Fragmentation/Diversification ofInternationalLaw, with Martti Koskenniemi as Special Rapporteur; ${ }^{20}$

- and the still ongoing Treaties over Time/Subsequent Agreements and Practice in Treaty Interpretation, with Georg Nolte as Special Rapporteur. ${ }^{21}$

17 ILA, "Final Report of the Committee - Statement of Principles Applicable to the Formation of General Customary International Law", in ILA, Report of the 6gth Conference (2000), pp. 712-778.

18 Michael Wood, "First Report on Formation and Evidence of Customary International Law", un Doc. A/CN.4/663 (17 May 2013); Michael Wood, "Second Report on Identification of Customary International Law", un Doc A/CN.4/672 (22 May 2014); Michael Wood, "Third Report on Identification of Customary International Law", un Doc. A/CN.4/682 (27 March 2015).

19 The mandate of which is two-pronged: codification of international law and progressive development.

20 Study Group of the International Law Commission, "Report on Fragmentation of International Law: Difficulties Arising from the Diversification and Expansion of International Law - Finalized by Martti Koskenniemi", un Doc. A/CN.4/L.682 (13 April 2006) (hereinafter ILC Study Group on Fragmentation).

21 Georg Nolte, "First Report on Subsequent Agreements and Subsequent Practice in Relation to Treaty Interpretation", un Doc. A/CN.4/66o (19 March 2013); Georg Nolte, "Second Report on Subsequent Agreements and Subsequent Practice in Relation to Treaty Interpretation", un Doc. A/CN.4/671 (26 March 2014); Georg Nolte, "Third Report on Subsequent Agreements and Subsequent Practice in Relation to Treaty Interpretation", UN Doc. A/CN.4/683 (7 April 2015). 
In addition to these, the ILA established as recently as May 2015, a Study Group on The Content and Evolution of the Rules of Interpretation, ${ }^{22}$ the aim of which will be to examine the problematic areas of the rules of interpretation their evolution through time and the difference in content on the basis of the document being interpreted.

However, a combination of both interpretation and CIL has so far never been fully researched. ${ }^{23}$ Nevertheless, it is the author's belief that within the context described, the time is now ripe for such an inquiry in order to further clarify the function of CIL by understanding the process of its interpretation, and as a result improve the reasoning and quality of international judgments and increase the predictability/foreseeability of the international legal system. What we need to find an answer to is, first of all, whether CIL can be interpreted in a manner similar to treaty rules and second, what is the content of the rules that govern this process of interpretation of CIL. Of course, an exhaustive analysis of these questions falls beyond the scope of this article. For this reason the analysis will focus mainly on the following issues. In Section 3, key concepts will be defined, i.e. deduction, induction and assertion as well as the difference between interpretation of CIL stricto sensu and interpretation of State practice as evidence of the existence of a rule of CIL. In Section 4, treaty and case-law evidence will be provided that demonstrates the interpretability of CIL. Finally, in Section 5 the analytical focus will turn on the interpretation of the CIL rules of interpretation of themselves. Cases will be presented where the relevant judicial bodies embarked on an interpretation of CIL rules on interpretation.

\section{Defining the Contours of the Notion of Interpretation of CIL}

Before demonstrating that the customary rules of interpretation can be the object of interpretation, certain issues and misconceptions need to be clarified.

22 ILA, "Study Groups", available at: http://www.ila-hq.org/en/study-groups/index.cfm/ cid/1057 (last accessed on 20 January 2016).

23 Although this topic also seems to be rising in importance, as will be demonstrated in the following Sections. Furthermore, one of the topics that the mandate of the aforementioned 2015 ILA Study Group describes as being within its ambit of research, is that of interpretation of CIL. 


\subsection{Induction vs. Deduction}

As mentioned above, CIL is one of the formal sources of international law. As stated in the North Sea Continental Shelf cases $^{24}$ and consistently affirmed in international jurisprudence, its existence is determined through examination of two elements, State practice and opinio juris. This process, from specific instances arriving at an identification of a more general rule, is an inductive process.

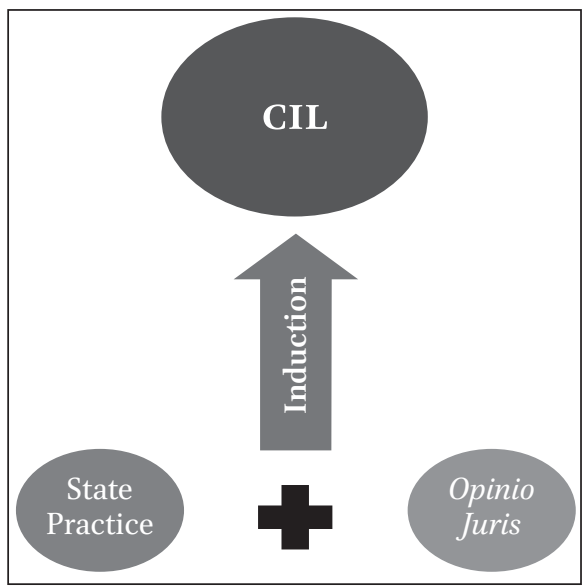

FIGURE 1 Formation of $C I L$.

However, since all rules, written or unwritten, despite having a "core of settled meaning" also have "a penumbra of uncertainty", ${ }^{25}$ this means that the inductive process of recourse to State practice and opinio juris will always be wanting. It will not in all instances be able to provide an answer as to whether a particular situation can be deemed as falling within the scope of meaning of a CIL rule. With respect to the other formal source of international law, treaties, this problem is resolved through the deductive process of interpretation, which bridges the gap between the existence of a treaty and its application. However, with CIL, if one rejects the possibility that CIL is subject to

24 North Sea Continental Shelf, supra note 12, 44.

25 H.L.A. Hart, "Positivism and the Separation of Law and Morals", 71/4 Harvard Law Review (1958), p. 607. 
interpretation, ${ }^{26}$ in a fashion similar to treaties, then we reach an absurdum. In such a scenario, CIL would have to be identified each and every time it is applied. The international judge would have to find each and every time sufficient State practice and opinio juris on each and every single topic that the CIL rule might relate to. Clearly this goes against any notion of rules, be they treaty or customary in nature, changing and evolving through time, and having a certain degree of content-flexibility in order to adapt in a changing legal and societal landscape. In addition to this, if cIL cannot be interpreted, then this would require of every CIL rule (an unwritten rule) such a degree of specificity that not even treaties (written texts) are expected to have. Such a discrepancy inescapably leads to absurd conclusions, and consequently the negation of the interpretation of CIL is a false premise.

In order to tackle the above concerns, various authors have argued in favour of a "deductive approach" for the identification of $\mathrm{CIL},{ }^{27}$ i.e. using methods other than reference to State practice and opiniojuris in order to determine the formation of a rule of CIL. It is at this point that an important distinction needs to be made. The proponents of the "flexible deductive approach" argue in favour of the existence of such an approach as either a methodological tool or as an alternative/emerging method of identification of CIL, that is in clear contrast with the classical inductive method of looking at State practice and opinio juris. Interpretation of CIL, on the other hand, is fundamentally different.

26 See, for instance, the following statements: "it is neither usual nor advisable to use the notion of interpretation in connection with the clarification of norms of customary law"; Rudolf Bernhardt, "Interpretation in International Law", in: Rudolf Bernhardt and Rudolf L. Bindschedler (eds.), Encyclopedia of Public International Law, Vol. II (1992), p. 1417; "the irrelevance of linguistic expression excludes interpretation as a necessary operation in order to apply [customary rules]"; Tullio Treves, "Customary International Law", MPEPIL 1393 (November 2006), para. 2, available at: http://www.mpepil.com (last accessed on 20 January 2016); "content merges with existence [and, thus, CIL cannot be interpreted]"; Maarten Bos, A Methodology of International Law (1984), p. 109. Similarly Degan holds that interpretation is restricted only to written treaties, therefore it cannot apply to verbal treaties, let alone CIL; Vladimir D. Degan, L' interprétation des accords en droit international (1963), p. 162.

27 Stefan Talmon, "Determining Customary International Law: the ICJ's Methodology between Induction, Deduction and Assertion", 26/2 EJIL (2015), p. 417; Anthea Roberts, "Traditional and Modern Approaches to Customary International Law: A Reconciliation", 95 AJIL (2001), p. 758; Alberto Alvarez-Jiménez, "Methods for the Identification of Customary International Law in the International Court of Justice's New Millennium Jurisprudence", 6o ICLQ (2011), pp. 686-689. 
Although it is a deductive process, it is neither a methodological tool, nor is it a method to determine the formation of CIL. Interpretation deals with identifying the content of a cIL rule, after it has come into existence. Interpretation of CIL is an inescapable result of the continued existence of a CIL rule through time. The fact that international judges sometimes apply the inductive process and others the deductive process of interpretation should not be erroneously considered as a matter of methodological choice. On the contrary, it an inescapable and direct result of the judges dealing with two different 'object-stages' in the 'life-cycle' of CIL. Rules of CIL do not have a momentary life-span. They continue to manifest themselves and produce legal effects through prolonged periods of time. This is exactly where the difference lies between the inductive and deductive approach to CIL. The inductive approach focuses on the formation of CIL, the emphasis is on how CIL comes into existence. However, once a CIL has been identified as having been formed, its continued manifestation and application in a particular case will be dependent on the deductive process of interpretation. In this manner, interpretation focuses on how the rule is to be understood and applied after the rule has come into existence and for its duration. Figure 2 explains the aforementioned schematically.

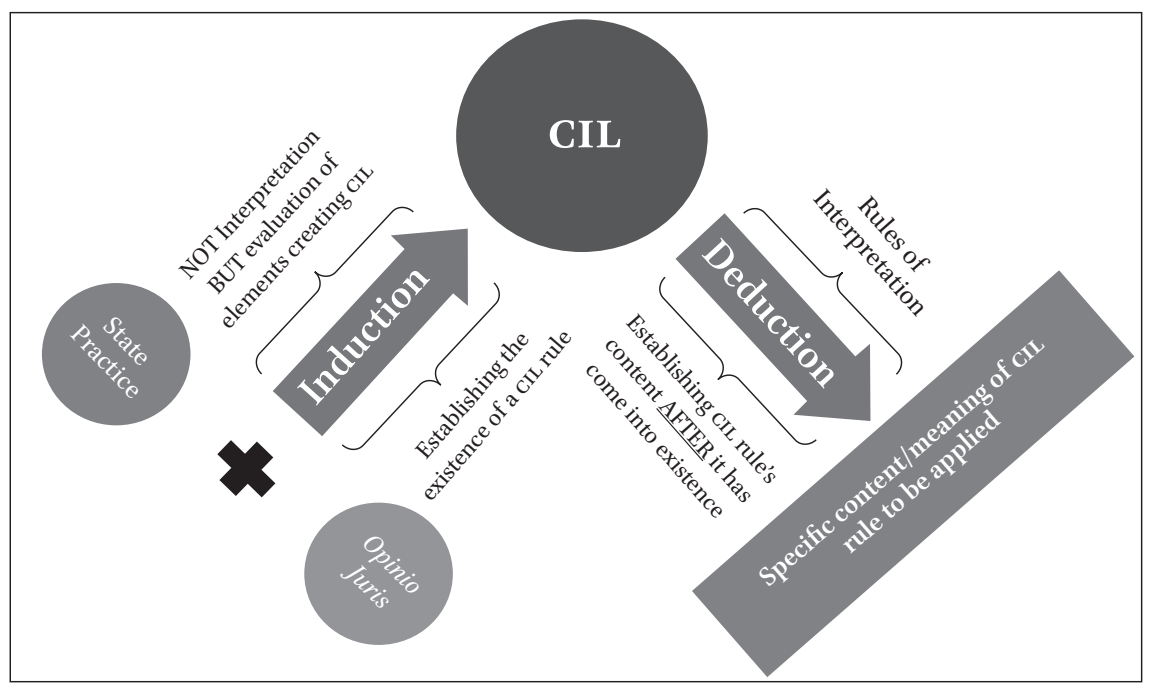

FIGURE 2 Proper place of interpretation in the life-cycle of CIL. 
It is these two different stages in the 'life-cycle' of CIL that are the raison d'être of the co-existence of the inductive and deductive approach to CIL, and which demonstrate the necessity for examining the rules that govern the process of interpretation of CIL.

\subsection{The Theoretical Dead-End of Assertion}

Whereas in the application of treaties the process of interpretation is one that must always yield a single solution, ${ }^{28}$ with respect to CIL the rules of interpretation of customary rules have not been examined. This leads to one of the following two paradoxical scenarios, if we do not accept the interpretability of CIL. Either CIL needs to be induced each and every time, by reference to state practice and opinio juris (but this is extremely problematic as it fails to take into account the continued existence, development and manifestation of CIL rules $)^{29}$ or CIL is to be asserted by international judges. ${ }^{30}$ Acknowledging assertion as a valid methodological tool for the identification of CIL would be tantamount to recognizing that international judges create law: they become law-makers and exercise a power to legislate (pouvoir de légiférer). However such a concession would go against any notion of separation of powers. An alternative understanding of 'assertion' is offered by Wood and Sender, who argue that "[u]nlike induction and deduction, assertion is self-evidently not a methodology for determining the existence of a rule of customary international law. It is essentially a way of drafting a judgment, a way of stating a conclusion". ${ }^{31}$ Irrespective of whether one views assertion as a slippery slope leading to an exercise of pouvoir de légiférer or a manner of drafting a judgment, what is

28 According to Sir Humphrey Waldock, "[c]learly, on the plane of interpretation, the treaty has only one correct interpretation" (emphasis added); Humphrey Waldock, "Sixth Report on the Law of Treaties", Un Doc. A/CN.4/186 and Add.1, 2/Rev.1, 3-7 (11 March - 14 June 1966), Draft Article 68 - Observations and Proposals of the Special Rapporteur, para. 9, reproduced in YILC Vol. II [1966], p. 90.

29 On the importance of ontological theories in international law in order to explain issues of identity, evolution, continuity and change, see Merkouris, supra note 14, pp. 125-128.

30 This option of assertion is identified by Talmon as methodological tool of identification of CIL (see Talmon supra note 27); however, although this is what in some cases judges may do, it is far removed from what they should do. This is nothing more than an example of the perennial conflict between Sein and Sollen.

31 Michael Wood and Omri Sender, "The International Court of Justice and Customary International Law: A Reply to Stefan Talmon", available at: http://www.ejiltalk.org/ the-international-court-of-justice-and-customary-international-law-a-reply-to-stefantalmon/ (last accessed on 20 January 2016) (emphasis added). 
common is that assertion is not a valid methodological tool for the determination of either the existence of the content of a CIL rule.

Both of the above described scenarios are untenable, so evidently in the study of CIL there is a critical gap in understanding how CIL can be applied in individual cases once it has been formed. This gap can only be filled through the process of interpretation of CIL.

\section{3 'Interpretation' of State Practice vs. Interpretation of CIL}

This brings me to my next point. Oftentimes in the study of CIL the term 'interpretation' is used rather loosely. This may lead to the erroneous conclusion that interpretation of CIL is nothing new, and is already extensively discussed. This could not be further from the truth. The reason for this misconception is that the word 'interpretation' is often used to describe the evaluation of State practice, ${ }^{32}$ or even more confusingly is used interchangeably to denote both 'interpretation of CIL' and 'interpretation of State practice leading to the formation of CIL. ${ }^{33}$ However, the linguistic misuse of the same term should not lead us to the erroneous conclusion that it is one and the same process. ${ }^{34}$ In the case at hand, it is the use of term 'interpretation' to describe two completely distinct processes that creates the fallacious impression that interpretation is ubiquitous in the formation of CIL, and therefore there is no need for attempting to identify the rules that govern the process. The critical flaw in this construction is that 'interpretation of State practice' is not interpretation in the strict legal sense (interpretatio stricto sensu). 'Interpretation' is used in similar fashion as 'evaluation'. What judges do is not interpret State practice, they evaluate it, they examine its gravity for the purpose of determining the existence or not of CIL. On the contrary, 'interpretation of CIL' requires an already existing CIL rule. Furthermore, not unlike interpretation of treaties, it is a process that follows certain rules and principles (for treaties it is Articles 31-33 VCLT and their CIL counterparts). Consequently, it is a process clearly distinct from the erroneously called 'interpretation of State practice', which should be properly called 'evaluation of State practice' to avoid confusion. It is

32 Charles de Visscher, Problémes d' interprétation judiciaire en droit international public (1963), pp. 219 et seq.

33 Frederick Schauer, "Pitfalls in the Interpretation of Customary Law", in A. PerreauSaussine and J.B. Murphy (eds.), The Nature of Customary Law (2007), pp. 13-34.

34 Serge Sur, L' interprétation en droit international public (1974), pp. 189-190; Alexander Orakhelashvili, The Interpretation of Acts and Rules in Public International Law (2008), p. 496. 
with respect to the 'interpretation of CIL' that research needs to be conducted in order to determine the rules that govern this strictly legal process. ${ }^{35}$

\section{$4 \quad$ Interpreting Customary International Law}

\subsection{Treaty Evidence}

Having established the basic precepts of interpretation of CIL, we can now move on to what is the main focus of the present Article, i.e. to prove the possibility of interpretation of the customary rules of interpretation. In this context it is useful to mention, albeit briefly, some of the most important indicia in international treaties and cases that demonstrate the interpretability of CIL.

Treaties would be a peculiar place to look for evidence that CIL can be interpreted. However, the Statutes of two international courts, and their preparatory work, do exactly that. The Rome Statute of the International Criminal Court (ICC) ${ }^{36}$ in Article 21, relating to applicable law, provides that the ICC "may apply principles and rules of law as interpreted in its previous decisions" 37 and that the "application and interpretation of law pursuant to this article must be consistent with internationally recognized human rights". 38

Similarly, in the preparatory work of the Statute of the Permanent Court of International Justice (PCIJ), the Advisory Committee of Jurists when discussing Article 36 of the PCIJ Statute had to choose between different versions of the Article. Two are the most apposite for the present analysis. The first one, based on a draft prepared by Lord Phillimore, ${ }^{39}$ provided for the jurisdiction of the PCIJ in all legal disputes concerning "... a. the interpretation of a treaty; b. any question of international law." 40 The second one was an amendment proposed by Ricci-Busatti that instead of the terms "question of international

35 On the acceptance of the interpretability of CIL, and the need to conduct research on the topic of the rules that govern it see: Kolb, supra note 15, pp. 219 et seq.; Denis Alland, "L interprétation du droit international public" 362 RdC (2014) pp. 82-88; Albert Bleckmann, "Zur Feststellung und Auslegung von Völkergewohnheitsrecht", 37 ZaöRV (1977), pp. 504-529; Orakhelashvili, supra note 34, Chapter 15; Merkouris, supra note 15, Chapter 4.

$36 \quad 1998$ Rome Statute of the International Criminal Court, 2187 UNTS 3 (hereinafter ICC Statute).

37 Ibid., Article 21(2) (emphasis added).

38 Ibid., Article 21(3) (emphasis added).

39 Advisory Committee of Jurists, Procès Verbaux of the Meetings of the Advisory Committee of Jurists: 16 June-24July 1920 with Annexes (1920), p. 252 (hereinafter Procès Verbaux).

$40 \quad 1920$ Statute of the Permanent Court of International Justice, 6 LNTS 379. 
law" used the terms "... b. the interpretation or application of a general rule of international law".41 In the end, the first version found its way in the final text of the PCIJ Statute and was later reproduced in the International Court of Justice (ICJ) Statute. However, that is not the result of a rejection of the interpretability of CIL. On the contrary, the discussion between the members of the Advisory Committee of Jurists reveals that prominent members considered this to be a much better wording than "any question of international law" that did not suffer from the pitfalls of the latter. ${ }^{42}$ However, the "any question of international law" was the wording eventually adopted, but this was done not on the merits of the wording itself, but for the purpose of ensuring continuity and consistency with previous treaties that had used the same wording. ${ }^{43} \mathrm{In}$ more detail:

[c]onsideration must be taken also of the important part this expression [i.e. 'any question of international law'] played in the Conferences of 1899 and 1907; as well as of legal conscience and world opinion which would be astonished not to find this term in the Committee's plan... Definite previous documents must be followed as much as possible, and it must not be forgotten that the expression used in the project is contained in Article 13 of the Covenant. ${ }^{44}$

\subsection{Case-Law Evidence}

Similarly with treaties, in international jurisprudence the evidence of interpretation of CIL is hidden in plain sight. So much so in fact that clear statements to that effect can be found in landmark cases, with which every first-year student of international law is familiar. The two most notable examples are the Nicaragua case and the North Sea Continental Shelf cases. In the former, the Court was of the view that "[r]ules which are identical in treaty law and in customary international law are also distinguishable by reference to the methods of interpretation and application", 45 thus clearly accepting the fact that

41 Procès Verbaux, supra note 40, p. 275 (emphasis added).

42 Ibid., pp. 264-265 and 283-284.

43 Ibid. The treaties that had used similar wording were: 1919 Covenant of the League of Nations, 1 LNTS 7, Article 13; 1899 Hague Convention for the Pacific Settlement of International Disputes, 187 CTS 410, Article 16; 1907 Hague Convention for the Pacific Settlement of International Disputes, 215 сTS 233, Article 38; 1903 Arbitration Treaty between Great Britain and France, XXIII Hertslet Treaties 492, Article 1; 1908 Treaty between the United States and Great Britain, xxv Hertslet Treaties 1203.

44 Ibid. at 265 .

45 Military and Paramilitary Activities in and against Nicaragua (Merits) (Nicaragua v. United States of America), Judgment, ICJ Reports 1986, para. 178. 
there are rules that guide the process of interpretation of CIL, although these will be, by virtue of the nature of CIL, different than those of treaties. This was stated more explicitly in the North Sea Continental Shelf cases, where Judge Tanaka opined in the following manner:

Customary law, being vague and containing gaps compared with written law, requires precision and completion about its content. This task, in its nature being interpretative, would be incumbent upon the Court. The method of logical and teleological interpretation can be applied in the case of customary law as in the case of written law. ${ }^{46}$

Although these two quotes, in and of themselves, should be enough to shatter any arguments surrounding the impossibility of interpretation of CIL, ${ }^{47}$ caselaw is peppered with numerous similar examples coming from a variety of international courts and tribunals and dealing with entirely different areas of international law. Indicatively, I mention Qatar v. Bahrain, ${ }^{48}$ EC-Biotech, ${ }^{49}$ EC - Large Civil Aircraft, ${ }^{50}$ Peru - Certain Agricultural Products, ${ }^{51}$ and cCFT v. USA (law of treaties), ${ }^{52}$ Nicaragua and Tadiç (state responsibility), ${ }^{53}$ Gulf of

$46 \quad$ North Sea Continental Shelf, supra note 12, Dissenting Opinion of Judge Tanaka, p. 181 (emphasis added). Similarly see ibid., Dissenting Opinion of Judge Morelli, p. 200.

47 See also the analysis infra in Section 5 on the logical and philosophical implications of proving a negative statement, i.e. 'CIL cannot be interpreted'.

48 Qatar v. Bahrain case, supra note 2, Dissenting Opinion of Vice-President Schwebel, pp. 27-39.

49 European Communities - Measures Affecting the Approval and Marketing of Biotech Products, WTO, Panel Report adopted on 21 November 2006, WT/DS291R, WT/DS292R and WT/DS293R, paras. 7.68-7.72. (hereinafter Ec-Biotech case).

50 European Communities and Certain Member States - Measures Affecting Trade in Large Civil Aircraft, WTo, Appellate Body Report adopted on 18 May 2011, WT/DS316/AB/R, para. 845 (hereinafter $E C$ - Large Civil Aircraft).

51 Peru - Additional Duty on Imports of Certain Agricultural Products, wTo, Appellate Body Report adopted on 20 July 2015, WT/DS457/AB/R, para. 5.101 (hereinafter Peru - Certain Agricultural Products).

52 Canadian Cattlemen for Fair Trade (CCFT) v. the United States of America, UNCITRAL, Award on Jurisdiction of 28 January 2008, paras. 50-51 and 187 (hereinafter CCFT V. USA case), available at: <http://www.italaw.com/sites/default/files/case-documents/itao114 .pdf> (last accessed on 20 January 2016).

53 Prosecutor v. Duško Tadić, ICTY, Appeals Chamber, Judgment of 15 July 1999, Case No. IT-94-1-A, para. 116. 
Maine, ${ }^{54}$ Fisheries ${ }^{55}$ and Tunisia v. Libya Continental Shelf (law of the sea), ${ }^{56}$ the Advisory Opinion on Nuclear Weapons (jus ad bellum and jus in bello), ${ }^{57}$ Barcelona Traction (diplomatic protection), ${ }^{58}$ and Alex Genin ${ }^{59}$ and Mondev (investment law).60

Elsewhere, I have offered a brief analysis of possible rules of interpretation of CIL using Tanaka's dictum on logical and teleological interpretation as a springboard. ${ }^{61}$ All the aforementioned examples and analysis should be sufficient to prove beyond the shadow of a doubt that CIL can be interpreted and that we should research the rules guiding that process. However, for the purposes of the present article, I have opted for going a step further, i.e. to demonstrate that even the rules of interpretation themselves have been the object of interpretation on multiple occasions. If even in this extreme and somewhat self-referential scenario, we can find evidence of CIL interpretation, then not only any objection to the interpretability of CIL can no longer be maintained but also it will be shown that the process of interpretation of CIL is so endemic to the application of CIL that it forms an integral part of its existence and application, and without which it can neither function properly nor its function be explained in a properly scientific manner.

Having established that interpretation of CIL is not only theoretical plausible, but essential in the 'life-cycle' of CIL, what will now be examined is whether

54 Delimitation of the Maritime Boundary in the Gulf of Maine Area (Canada/United States of America), Judgment, ICJ Reports 1984, para. 111.

55 Fisheries (the United Kingdom v. Norway), Judgment, ICJ Reports 1951, Separate Opinion of Judge Hsu Mo, pp. 154-155.

56 Continental Shelf (Tunisia v. Libyan Arab Jamahiriya), Judgment, ICJ Reports 1982, paras. 38 and 70 (emphasis added).

57 Legality of the Threat or Use of Nuclear Weapons, Advisory Opinion, ICJ Reports 1996, Separate Opinion of Judge Ranjeva, pp. 299-300; ibid., Dissenting Opinion of Judge Shahabuddeen, p. 398; ibid., Dissenting Opinion of Judge Higgins, paras. 24 and 32.

58 Barcelona Traction, Light and Power Company, Ltd. (Second Phase) (Belgium v. Spain), Judgment, ICJ Reports 1970, para. 54.

59 Alex Genin, Eastern Credit Ltd., Inc. and A.S. Baltoil Genin v. Republic of Estonia, ICSID, Award of 25 June 2001, ICSID Case No. ARB/99/2, para. 367.

6o Mondev International Ltd. v. United States of America, ICSID, Award of 11 October 2002, ICSID Case No. ARB(AF)/99/2, para. 113 .

61 Merkouris, supra note 15 , Chapter 4. 
even the customary rules of interpretation themselves can be the object of interpretation. It has to be noted that this exercise is not necessary in order to prove the interpretability of CIL, and this is perhaps the Sisyphean nature of the task of those rejecting the interpretability of $\mathrm{CIL}^{;}{ }^{62}$ the near impossibility of proving a negative. This issue has been discussed extensively in linguistics, philosophy and mathematics. By arguing that 'CIL cannot be interpreted', one has to prove that for each and every situation CIL cannot and has not been interpreted. On the other hand, those, the present author included, who argue that 'CIL can be interpreted' have only to find one (only one) example of such an interpretation in order to disprove the original statement. The classical example is the so-called 'black swan' example. The statement 'all swans are white' is based on the premise, 'no swan can have any other colour other than white. Every white swan discovered reinforces that statement, but cannot prove it. On the other hand, the discovery of just one black swan ${ }^{63}$ can completely disprove the first statement. Consequently, the probative value of each instance is widely different. In the present case, I have already provided numerous examples of interpretation of CIL, of 'black swans'. However, and in order to demonstrate how wide-spread and integral to the function of CIL is its interpretation, I will in this Section prove that not only some customary rules can be interpreted, but even the rules of interpretation themselves. If even in this extreme case, where we have what amounts to a self-referential set, we can prove that the customary rules of interpretation can be the object of interpretation, then by application of the logical principle a majore ad minus, it is evident that interpretation of CIL is relevant for each and every rule of CIL.

\subsection{Interpretation of Article 31(3)(a) \&(b) VCLT as Customary Law}

In our inquiry into examples of interpretation of the customary rules of interpretation, the work of the ILC proves to be extremely useful. In 2008 the ILC

\footnotetext{
62 See supra note 26.

63 This refers to the well-known example of falsifiability of universal generalizations. For instance, the statement, "all swans are white" can be disproven by the observation of a single black swan (swans of such colour can be found in New Zealand and Australia). In the same fashion, the statement "no CIL rule can be interpreted" can be disproven even by a single instance where a CIL has been interpreted (the process, through which from an observation of CIL rules being interpreted to come to the conclusion that the statement "no cIL rule can be interpreted" is false, is known as modus tollens). In more detail on the problem of induction and falsifiability see: Karl Popper, The Logic of Scientific Discovery (London: Routledge, 2002).
} 
decided to include the topic 'Treaties over Time' in its programme of work. ${ }^{64}$ So far three reports have bene produced by the Special Rapporteur Georg Nolte, all of which offer valuable examples of instances of interpretation of Article $31(3)(a)$ and (b) vCLT and their customary law counterparts. ${ }^{65}$ Going through these reports, one will come across many instances where there is very limited State practice and opinio juris on a particular issue. Despite this there are some limited cases that have provided answers, sometimes contradictory ones. ${ }^{66}$ Clearly in these situations, it cannot be argued that there the material and psychological element of custom is met. Consequently, all these instances are nothing more than different interpretations of the same customary rule. Such interpretations may at a future time reach the required level of density of practice and opinio juris, but for the time being since that is not the case, they cannot be considered as the established content of an existing customary rule, but rather an interpretation of the general customary rule, i.e. an interpretation of Article 31(3)(a) and (b) CIL.

The aim in this Section is not to provide based on these reports an extensive and exhaustive list of all such cases where interpretation of the customary law equivalents of Article 31(3)(a) and (b) $\operatorname{VCLT}^{67}$ occurred, but rather to highlight some of the most interesting examples that will more than suffice to prove that the CIL rules of interpretation can and have been interpreted in international case-law.

One such example is whether decisions of the Conference of the Parties or Meeting of the Parties (COP/MOP decisions) not adopted in the presence of all the parties, can be assumed to fall under Article 31(3)(a) despite the lack of an explicit expression of consent by the missing parties. Two points need to be underlined in this scenario. Firstly, there exists no international case, let alone sufficient practice and opinio juris, addressing this specific point. Second, a similar issue has been raised quite a few times with respect to Article 32 and it was also the object of a similar process of interpretation. ${ }^{68}$ But coming back

64 Official Records of the General Assembly, Sixty-third Session, Supplement No. 10 (A/63/10), para. 353 .

65 The text of Article 31(3)(a) and (b) vcLT goes as follows: "There shall be taken into account, together with the context: (a) Any subsequent agreement between the parties regarding the interpretation of the treaty or the application of its provisions; (b) Any subsequent practice in the application of the treaty which establishes the agreement of the parties regarding its interpretation".

66 See in more detail, case-law analysed in: Nolte, "First Report", supra note 21 and Nolte, "Second Report", supra note 21.

67 For reasons of convenience, these will be referred to as Article 31(3)(a) and (b) CIL.

68 See infra, Section 5.3. 
to the point at hand, the ILC concluded that in the case of COP/MOP decision that would be an Article 31(3)(a) subsequent agreement if all the parties had adopted it, this would also be the case even if one or more parties did not participate in the Conference, as long as certain conditions were met.

It would be difficult to assume that a party to a treaty has agreed, by its consent to be bound by the treaty, to accept decisions which are subsequently taken in its absence by other States parties within the framework of the Conference of States Parties concerned. It should therefore be possible for non-participating States to subsequently express their disagreement with a decision that was taken within the framework of a Conference of States Parties. On the other hand, the principle of good faith and the duty to cooperate within the treaty framework speak in favour of a duty of non-participating States to articulate their possible disagreement as soon as possible under the circumstances; otherwise their agreement in the form of silence (acquiescence) would have to be assumed. ${ }^{69}$

The whole structure of this paragraph clearly demonstrates that this is an example of logical, teleological and systemic interpretation. All the inferences that are made regarding whether the COP/MOP decisions fall under Article 31(3)(a) (both VCLT and CIL), are not based on State practice and opinio juris since none exists, but rather on logical assumptions based on the object and purpose of the rule, as well as by reference to other rules/principles of international law such as the principle of good faith and the duty to cooperate (systemic interpretation). So, clearly this is an example of interpretation of Article 31(3)(a) CIL.

Another example comes from a NAFTA Panel in the Cross-Border Trucking Services, where it rejected the possibility of interpretative recourse to domestic law. In a Section discussing the rules of interpretation the Panel, does a volte face and refers to Article 27 VCLT. In detail:

in light of the fact that both Parties have made references to their national legislation on land transportation, the Panel deems it appropriate to refer to Article 27 of the Vienna Convention, which states that 'a party may not invoke the provisions of its internal law as justification for its failure to perform a treaty.' This provision directs the Panel not to examine national laws but the applicable international law. Thus, neither the internal law of the United States nor the Mexican law should be utilized for the

69 Nolte, "Second Report", supra note 21, para. 109 (emphasis added). 
interpretation of NAFTA. To do so would be to apply an inappropriate legal framework. ${ }^{70}$

This reference to Article 27 of the VCLT although seemingly untethered to the overall interpretative discussion, is in actuality nothing more than another example of systemic interpretation of Article 31(3)(b) CIL. While discussing the customary rules of interpretation, and in order to conclude that domestic law is not an interpretative element to be taken into account, it refers to a relevant rule of international law, the VCLT and in particular Article 27. Despite the fact that this interpretation of Article $31 \mathrm{CIL}$, in the author's opinion, is erroneous, a feeling shared by other courts and tribunals and the ILC, ${ }^{71}$ this does not detract from the fact that it is another example of interpretation of CIL rules of interpretation. ${ }^{72}$

The World Trade Organization (wTo) Appellate Body, in Us - Clove Cigarettes, also resorted to the terms used in the VCLT, in order to interpret Article $31(3)(\mathrm{a})$ CIL. ${ }^{73}$ In determining whether paragraph 5.2 of the Doha Ministerial Decision could be considered as a "subsequent agreement" it referred to the terms, or lack thereof, used in Article 31(3)(a) VCLT and from that deduced that the term 'agreement' established a requirement more of substance rather than form (both logical and systemic interpretation). At no point did the judicial reasoning touch upon the issue of whether this solution was evidenced by State practice and opinio juris.

We note that the text of Article 31(3)(a) of the Vienna Convention does not establish a requirement as to the form which a 'subsequent agreement between the parties' should take. We consider, therefore, that the term 'agreement' in Article 31(3)(a) of the Vienna Convention refers, fundamentally, to substance rather than to form. Thus, in our view, paragraph 5.2 of the Doha Ministerial Decision can be characterized as a 'subsequent agreement'... provided that it clearly expresses

70 In the matter of Cross-Border Trucking (Mexico vs. United States of America), NAFTA, Final Report of the Panel of 6 February 2001, Secretariat File No. USA-MEX-98-2008-01, para. 224.

71 Nolte, "First Report", supra note 21, paras. 113-115 and cases cited therein.

72 Not to mention that some of the cases where the international courts resorted to domestic law as a form of "subsequent practice" or "supplementary means" did so, originally, also by virtue of an interpretative process.

73 Note that the wTo Panels and Appellate Body according to the DSU are to apply the customary rules of interpretation, not the VCLT as such. 
a common understanding, and an acceptance of that understanding among Members... ${ }^{74}$

Of course, the Reports on "Subsequent agreements and subsequent practice in relation to interpretation of treaties" are rife with numerous other examples of interpretation Article 31(3)(a) and (b) CIL ${ }^{75}$ but the ones mentioned should more than suffice to illustrate that Article 31(3)(a) and (b) CIL has been and continues to be the object of interpretation.

\subsection{Interpretation of Article 31(3)(c) VCLT as Customary Law}

The principle of systemic integration, enshrined in Articles 31(3)(c) VCLT, provides that, together with the context, account shall be taken of "any relevant rules of international law applicable in the relations between the parties". Each and every element of this provision ${ }^{76}$ raises significant interpretative issues. ${ }^{77}$ However, for the purposes of this article the most revealing one is what is the proper interpretation of the term 'parties'? Should it be understood as 'parties to the treaty' or 'parties to the dispute'? Depending on the approach taken this will have long-term knock-on effects as to the rules that can be taken into account for interpretative purposes under Article $31(3)$ (c). If one accepts the interpretation of 'any party to the treaty', this means that all parties to the treaty being interpreted must be parties to the treaty being invoked under Article $31(3)$ (c). This, of course, especially in the case of multilateral treaties would significantly restrict the pool of treaties, to which an international judge could resort to for interpretative inspiration. On the other hand, if 'parties to the dispute' is the interpretation given to Article 31(3)(c) then the common parties between the treaties need be only the two parties to the dispute. Consequently,

74 United States - Measures Affecting the Production and Sale of Clove Cigarettes, wTо, Appellate Body Report adopted on 4 April 2012, WT/DS406/AB/R, para. 267.

75 Indicatively, whether in cases of "serial bilateralism" (Eyal Benvenisti and George W. Downs, "The Empire's New Clothes: Political Economy and the Fragmentation of International Law", 6o Stanford Law Review (2007), pp. 610-661), the bilateral treaties should be considered as either "subsequent practice" or "supplementary means" (Nolte, "First Report", supra note 21, paras. 81-83); or that the question whether a particular form of practice can be considered as State practice, will be determined by reference to the customary rules of attribution (systemic interpretation) (Nolte, "First Report", supra note 21, paras. 120-124).

76 Alongside with some elements that were eventually left on the cutting floor of the Vienna Conference.

77 For a detailed analysis, see Merkouris, supra note 15. 
the range of treaties that would fall within the ambit of Article 31(3)(c) would be much greater.

One of the most-cited cases regarding Articles 31(3)(c) is the EC-Biotech. In that case, the wто Panel had to find whether treaties could be taken into account under Article 31(3)(c). In doing so, it concluded that:

This understanding of the term "the parties" leads logically to the view that the rules of international law to be taken into account in interpreting the wTO agreements at issue in this dispute are those which are applicable in the relations between the wTо Members... Taking account of the fact that Article 31(3)(c) mandates consideration of other applicable rules of international law, and that such consideration may prompt a treaty interpreter to adopt one interpretation rather than another, we think it makes sense to interpret Article $31(3)$ (c) as requiring consideration of those rules of international law which are applicable in the relations between all parties to the treaty which is being interpreted. ${ }^{78}$

This led many to conclude that the Panel in EC-Biotech had opted for the 'parties to the treaty' interpretation of Article 31(3)(c) (restrictive interpretation). However, that is not accurate at all. Although indeed the Panel was inclined to consider that interpretation as the more appropriate one in the case at hand, the Panel made it abundantly clear that:

Before applying our interpretation of Article 31(3)(c) to the present case, it is important to note that the present case is not one in which relevant rules of international law are applicable in the relations between all parties to the dispute, but not between all wто Members, and in which all parties to the dispute argue that a multilateral WTO agreement should be interpreted in the light of these other rules of international law. Therefore, we need not, and do not, take a position on whether in such a situation we would be entitled to take the relevant other rules of international law into account. ${ }^{79}$

Consequently, the only firm position it took was that Article 31(3)(c) could not be interpreted as 'any one of the parties to the dispute'. However, what is significant is how the Panel arrived at this conclusion. First of all, I would like to draw the readers' attention to the fact that in the span of five paragraphs $(7.68-7.72)$ the Panel refers to interpretation or understanding of the terms of

78 EC-Biotech, supra note 50, paras. 7.69-7.70.

79 Ibid., para. $7 \cdot 72$. 
Articles $31(3)(c)$ no less than 13 times. Consequently, the Panel is well aware that it is engaged in an interpretative process.

In addition to this, the Panel is not interpreting Article 31(3)(c) VCLT but its equivalent in CIL. ${ }^{80}$ Pursuant to Article 3.2 of the Dispute Settlement Understanding (DSU) the WTo Panels and Appellate Body interpret the WTO agreements "in accordance with customary rules of interpretation of public international law." Consequently, they cannot and do not apply the vCLT but CIL. When they are talking about the interpretation of Article 31(3)(c), they are not interpreting the VCLT provision but CIL. Of course, one could argue that they are interpreting the VCLT provision ${ }^{81}$ and then transposing that interpretation to CIL. But such an argument is still far removed from the classical approach of identifying the existence of a customary rule through State practice and opinio juris. The only manner in which such a process can be explained without rending asunder the theoretical fabric of the sources of international law, is by accepting that CIL is being interpreted and that the VCLT is referred to as a document that can be taken into account for interpretative purposes. But such a description leads us inescapably to the conclusion that the VCLT is being resorted to because it is a 'relevant rule' for the purposes of interpretation of the Article 31(3)(c) CIL. Consequently, codification (or partly codification) treaties and in this case the rules of interpretation in the VCLT, are resorted to in the context of the principle of systemic integration. The Panel in EC-Biotech interpreted Article 31(3)(c) CIL by reference to the text and context of Article 31(3)(c) VCLT, as a 'relevant rule'.

But this is not the end of the line of reasoning and, in fact, this final step of legal analysis demonstrates the dangers and creeping inconsistencies that emerge as a direct result of a lack of discussion on the interpretability of CIL and the rules regulating that process. As mentioned above, the Panel felt that the restrictive interpretation of Article 31(3)(c) was the one indicated by the text and context of the VCLT. However, as demonstrated above, such reference to the VCLT was interpretatively permitted only by virtue of Article 31(3)(c) CIL. But not all the parties to the dispute were parties to the VCLT. Neither the European Communities nor the USA are parties to it. Consequently, the Panel referred by virtue of Article 31(3)(c) CIL to a 'relevant rule applicable in the relations between some of the parties to the dispute' in order to conclude that Article 31(3)(c) CIL is to be read as 'relevant rules applicable in the relations between all the parties to the treaty'. In essence, the Panel disproved what it had axiomatically relied on in order to reach an interpretative conclusion.

8o For reasons of convenience, this will be referred to as Article 31(3)(c) CIL.

81 Although this would per se be problematic as the VCLT and its interpretation does not fall within the jurisdiction of the wTo Dispute Settlement Bodies. 
It concluded $-x$ based on a line of reasoning that was premised on the assumption that the conclusion cannot be $-x$. Or in set theory terms, in order for $-\mathrm{x} \in 3^{1}(3)$ (c), - $\mathrm{x} \notin 31(3)$ (c). This is a clear argumentum ad absurdum, as an interpretation of Article 31(3)(c) and its opposite cannot be valid at the same time.

Later WTO cases steered clear of this controversy, by focusing more on the interpretation of the term 'relevant'. ${ }^{82}$ In particular, in Ec-Large Civil Aircraft and Peru - Additional Duty on Imports of Certain Agricultural Products, the wTo Appellate Body opined that

... we recognize that a proper interpretation of the term 'the parties' must also take account of the fact that Article 31(3)(c) of the Vienna Convention is considered an expression of the 'principle of systemic integration. ${ }^{83}$

It then interpreted Article 31(3)(c) by reference to the VCLT, to principles of good faith, pacta sunt servanda and the principle of effectiveness ${ }^{84}$ (all examples of systemic interpretation), but also to the "purpose of treaty interpretation"85 (which is an example of teleological interpretation). Consequently, the WTO jurisprudence on Article (3)(c) CIL, seems to confirm the preliminary findings of Judge Tanaka in the North Sea Continental Shelf cases.

\subsection{Interpretation of Article 32 VCLT as Customary Law}

With respect to the interpretation of the customary rule on recourse to supplementary means of interpretation, three areas have been selected that in the author's view best highlight the fact that Article 32 CIL has also been subjected to the process of interpretation. ${ }^{86}$

The first area concerns the scope ratione materiae of the rule, more specifically what is to be considered as supplementary means. In CCFT v. USA the Tribunal devotes an entire Section of its reasoning to qualifying reference to other judicial decisions as 'supplementary means'. Essentially, the Tribunal

82 EC - Large Civil Aircraft, supra note 51, para. 845; Peru - Certain Agricultural Products, supra note 52, para. 5.101.

83 EC - Large Civil Aircraft, supra note 51, para. 845 (emphasis added).

84 Ibid.

85 Ibid.

86 The text of Article 32 VCLT goes as follows: "Recourse may be had to supplementary means of interpretation, including the preparatory work of the treaty and the circumstances of its conclusion, in order to confirm the meaning resulting from the application of article 31, or to determine the meaning when the interpretation according to article 31: (a) Leaves the meaning ambiguous or obscure; or (b) Leads to a result which is manifestly absurd or unreasonable". 
embarks on an interpretative process through which it attempts to determine that judicial decisions are included in the more 'generic term' of 'supplementary means'. It does this by referring to the terms used in two treaties; Article 32 VCLT and Article $38(1)(d)$ of the ICJ Statute. ${ }^{87}$ Interesting is the fact, which unfortunately we have seen repeated on multiple occasions already, that despite CIL being the applicable law since USA has not ratified the VCLT, the Tribunal immediately goes to that treaty and starts its interpretative process by breaking down the meaning of the words used in Article 32. This recourse to 'codification treaties' is nothing more than an example of logical/systemic interpretation of CIL. ${ }^{88}$ But to make matters even more interesting the Tribunal resorts to systemic interpretation not once but twice. It considers that Article $38(1)(d)$ of the ICJ Statute is also a 'relevant rule' of international law that can be useful in the interpretation of what can be considered as supplementary means. According to the Tribunal "Article $38[(1)(\mathrm{d})]$ of the Statute of the International Court of Justice provides that judicial decisions are applicable for the interpretation of public international law as 'subsidiary means'. Therefore, they must be understood to be also supplementary means of interpretation in the sense of Article 32 $V C L T " .89$ Of course, one can criticize the leaps in logic that the Tribunal takes, when equating 'supplementary' with 'subsidiary', ${ }^{90}$ however, the fact remains that the Tribunal engaged in a process of systemic interpretation of Article 32 CIL, where it took account not one but two 'relevant rules of international law', Article 32 VCLT and Article 38 ICJ Statute.

A similar systemic interpretation was conducted by a wTO Panel in $E C-$ Chicken Classification, ${ }^{91}$ but there the Panel, referring again to the VCLT, concluded that judicial decisions ${ }^{92}$ could be considered not as 'other supplementary means' but specifically as 'circumstances of conclusion'. ${ }^{93}$ Not only that but on the basis of the wording and the telos of Article $3^{2}$ VCLT it also

\footnotetext{
$87 \quad$ CCFT V. USA case, supra note 53, paras. 50-51 (emphasis in original).

88 See Merkouris, supra note 15 , Chapter 4.

89 CCFT V. USA case, supra note 53, para. 187.

9o Since the former was selected to indicate a degree of sub-ordinance of this source compared to the formal sources of international law, whereas the latter was selected to underscore that interpretation was a holistic exercise.

91 European Communities - Customs Classification of Frozen Boneless Chicken Cuts, wTo, Panel Report adopted on 30 May 2005, WT/DS269/R and WT/DS286/R (hereinafter Ec Chicken Classification (PR)).

92 Specifically two judicial decisions: $C$-175/82, Hans Dinter GmbHv. Hauptzollamt Köln-Deutz, CJEU, Judgment of 17 March 1983; C-33/92, Gausepohl-Fleisch GmbH v. Oberfinanzdirektion Hamburg, CJEU, Judgment of 27 May 1993.

93 EC-Chicken Classification (PR), supra note 92, para. $7 \cdot 391$ and footnote 681.
} 
concluded that for determining whether a judicial decision falls within the ambit of 'circumstances of conclusion', two criteria exist: i) relevance and ii) temporal proximity. ${ }^{94}$ Consequently, and although the wTо Panel came to a different qualification of judicial decisions, its conclusion was arrived at through an interpretative process mostly systemic (by reference to the VCLT) but also partly teleological (by reference to the object and purpose of the rule).

In another set of cases, the scope ratione materiae of Article $32 \mathrm{CIL}$ once again became the object of interpretation, but this time the issue in question was whether preparatory work could be invoked against or by States that were not amongst the original signatories of a treaty and had not participated in the negotiations of the treaty in question. Although the issue seems to have been resolved nowadays in the affirmative, provided that the conditions of accessibility and publication are satisfied, and arguably attained the level of customary law, originally this was not such a clear issue. The international courts and tribunals that dealt with this problem came to diverging conclusions, with some finding against the invocation of preparatory work against 'third States, ${ }^{95}$ while others in favour of it. ${ }^{96}$ What is critical for the present analysis is that irrespective of the final conclusion, the process through which the courts and tribunals arrived at it was not an inductive one, focused on establishing State practice and opinio juris, but rather a deductive/interpretative one, focusing on the object and purpose of the rule (teleological interpretation), as well as the existence of other relevant rules of international law with which the recourse to preparatory work should not conflict, such as the principles of res inter alios acta and the pacta tertiis nec nocent nec prosunt (i.e. a systemic interpretation).

A final set of cases regarding the interpretation of the customary rule of recourse to preparatory work involves questions of whether preparatory work

94 Ibid., paras. 7.344 and 7.390-7.392.

95 Territorial Jurisdiction of the International Commission of the River Oder (the United Kingdom, Czechoslovakia, Denmark, France, Germany and Sweden v. Poland), Order of 20 August 1929, PCIJ Series A No. 23, p. 42; Young Loan Arbitration (the United Kingdom, United States of America, France, Belgium and Switzerland v. Federal Republic of Germany), Award of 16 May 1980, 59 ILR (1980), pp. 544-547.

96 Always under the condition of publication and/or accessibility: Aerial Incident of 27 July 1955 (Israel v. Bulgaria), Judgment, ICJ Reports 1959, pp. 140 et seq.; ibid., Joint Dissenting Opinion by Judges Sir Hersch Lauterpacht, Wellington Koo and Sir Percy Spender, pp. 179180; Italy v. Federal Republic of Germany, Decision of 14 November 1959, 29 ILR (1966), pp. 46o-470; Government of the Kingdom of Greece (in behalf of Apostolidis) v. Federal Republic of Germany, Decision of 11 May 1960, 34 ILR (1967), pp. 242-245; United States - Safeguard Measures on Import of Fresh, Chilled or Frozen Lamb Meat from New Zealand and Australia, wTo, Panel Report adopted on 16 May 2001, WT/DS177/R and WT/DS178/R, paras. 7.110 et seq. 
can be used to correct/rectify the meaning of the text. Once again, there is very limited State practice and opinio juris on the matter, so no argument could be raised that any solution to this question has already attained customary law status. International judicial practice has equally been divided on the matter, with the solutions given ranging from outright rejection of a 'corrective function' to interpretation, ${ }^{97}$ to acceptance of the theoretical plausibility of such a function being part of Article $32 \mathrm{CIL},{ }^{98}$ up to actually resorting to preparatory work in order to correct the meaning of the text. ${ }^{99}$ However, once again, and irrespective of the wide range of interpretations offered, all of them revolve around the exact same attractors as in all the cases mentioned in this Section; the logic and teleology of Article $32 \mathrm{CIL}$. Amongst these cases, Qatar v. Bahrain is perhaps the most illustrative example as there Judge Schwebel in his Dissenting Opinion analysed in extenso his interpretation of Article $32 \mathrm{CIL} .{ }^{100}$ First, he expresses the view that contrary to what the Court said, he was of the view that the meaning of the Arabic expression 'al-tarafan', which was the crux of the interpretative dispute, was not clear. ${ }^{101}$ However, even if one took

97 Jurisdiction of the European Commission of the Danube between Galatz and Braila, Advisory Opinion, PCIJ Series B No. 14, p. 31. (hereinafter Jurisdiction of the Danube Commission Advisory Opinion).

98 Polish Postal Service in Danzig, Advisory Opinion, PCIJ Series B No. 11, pp. 6 et seq.; S.S. Lotus (France v. Turkey), Judgment, PCIJ Series A No. 10, p. 17; Payment of Various Serbian Loans Issued in France (France v. Serbia), Judgment, PCIJ Series A No. 20, p. 30; Payment in Gold of the Brazilian Federal Loans Issued in France (France v. Brazil), Judgment, PCIJ Series A. No. 21, pp. 114-115; Interpretation of the Statute of the Memel Territory (Preliminary Objection) (the United Kingdom, France, Italy and Japan v. Lithuania), Judgment, PCIJ Series A/B No. 47, pp. 249-253; North Atlantic Coast Fisheries Case (Great Britain v. United States of America), PCA, Award of 7 September 1910, XI RIAA (1961), p. 186; Roumanian Minister of Warv. The Turkish Government (Romania v. Turkey), Award of 26 April 1928, vi Tribunaux Arbitraux Mixtes (1928), p. 996; Cayuga Indians (Great Britain) v. United States of America, Award of 22 January 1926, VI RIAA (1955), p. 184. Generally, see: Hersch Lauterpacht, "Les travaux préparatoires et l' intérpretation des traités", 48/II $R d C$ (1934), p. 789.

99 Qatar v. Bahrain case, supra note 2, Dissenting Opinion of Vice-President Schwebel, pp. 27-39; Boundaries in the Island of Timor (Netherlands v. Portugal), PCA, Award of 25 June 1914, XI RIAA (1961), p. 502; Polyxene Plessa v. the Turkish Government (Greece v. Turkey), Award of 9 February 1928, viII Tribunaux Arbitraux Mixtes (1929), pp. 224 et seq.; Eastern Bank Ltd. v. the Turkish Government (the United Kingdom v. Turkey), Award of 28 December 1927, VIII Tribunaux Arbitraux Mixtes (1929), p. 188; Antippa v. Germany (Greece v. Germany), Award of 3 November 1926, vir Tribunaux Arbitraux Mixtes (1928).

100 Qatar v. Bahrain case, supra note 2, Dissenting Opinion of Vice-President Schwebel, pp. 27-39.

101 The issue was whether this term should be interpreted as 'either of the parties' or 'both parties jointly'. 
the Court's view that it was clear, he was of the opinion that preparatory work proved that the opposite interpretation was the correct one. Consequently, the issue arose of preparatory work leading to a different interpretation that that of the so-called 'ordinary meaning'.

Schwebel rightly points out that the solution to this conflict is not to be found in customary law. ${ }^{102}$ Consequently, and in order to provide an answer he takes the following steps. He refers to the VCLT and its preparatory work as a 'relevant rule of international law' (systemic interpretation) ${ }^{103}$ and to the primary object and purpose of treaty interpretation which is "the revealing of the intention of the parties" (teleological interpretation). ${ }^{104}$ This leads him to the conclusion that preparatory work can have, apart from a confirmatory and determinative function, a corrective one as well. He reinforces this conclusion by another instance of systemic interpretation. He suggests that not allowing preparatory work to correct the meaning of the text would be contrary to another 'relevant rule of international law', i.e. the principle of good faith. ${ }^{105}$

In this article the question put forward was whether the customary rules of interpretation could also be the object of interpretation. As a first step in that direction, some common misconceptions had to be dispelled. It was demonstrated that interpretation of CIL was a reflection of the continued manifestation of CIL rules as rules of international law. Whereas the inductive process of establishing the existence of sufficient State practice and opinio juris was required in order for determining the existence of a CIL rule, its application in a variety of instances rested squarely upon the deductive process of interpretation. Consequently, the inductive and deductive processes were not merely methodological tools to be used at will and interchangeably but were reflections of the different stages in the 'life-cycle' of a cIL rule. The inductive process was apposite to the stage of determining the existence of CIL rule. The deductive process of interpretation, on the other hand, was apposite to

102 Qatar v. Bahrain case, supra note 2, Dissenting Opinion of Vice-President Schwebel, pp. $3^{1-32 .}$

103 Ibid., pp. 29-31.

104 Ibid., p. 27.

105 Ibid., p. 39. One could also add here that it would also rob the customary rule enshrined in Article 32 VCLT of its effectiveness and in that sense would also be contrary to the principle ut res magis valeat quam pereat (principle of effectiveness). 
determining the content of the rule after it had been established that it had come into existence. Another common misconception that had to be resolved was that interpretation of State practice is not the same as 'interpretation of CIL'. In fact, it not even 'interpretation' in the proper, legal sense of the word. Rather it is evaluation.

Having set the definitional framework for the present article, the analysis shifted to a brief demonstration that CIL can and has been interpreted with respect to a variety of CIL rules. Evidence was provided both with respect to treaties and to international case-law. The most revealing of these, was Judge Tanaka's identification of some of the rules of interpretation of CIL, i.e. the logical (or systemic) teleological interpretation. Armed with this, the analytical lens was turned to examining whether these rules of interpretation of CIL could apply even in the extreme and somewhat self-referential scenario of interpretation of the customary rules of interpretation. Even though from a discursive point of view, even one example would suffice to disprove the negation of the interpretability of both the customary rules of interpretation and, more generally, of CIL as such, it was shown that the interpretation of the customary rules of interpretation is not only a reality but even more so a relatively common occurrence. A far from exhaustive analysis of the existing jurisprudence revealed a cornucopia of cases where Articles 31 and 32 CIL had been interpreted and in a manner reaffirming Tanaka's dictum. Although this proof signalled the end of the purpose of this article, it can only be hoped that the uncovering of such a vast and mostly unchartered area in the field of both interpretation and CIL will lead to more detailed examinations and discussion on the topic of interpretation of CIL. 